\title{
Skin Basal Cell Carcinoma with Sebaceous Differentiation
}

National Cancer Institute

\section{Source}

National Cancer Institute. Skin Basal Cell Carcinoma with Sebaceous Differentiation. NCI

Thesaurus. Code C4346.

A basal cell carcinoma of the skin that is characterized by sebaceous differentiation. 